\title{
Dworkin's Unfinished Task
}

\section{Philip Selznick $\uparrow$}

For the appreciative reader of Ronald Dworkin's writings, his explicit recognition of the place of coininunity in inoral judgment should coine as no surprise. That recognition was implicit in his powerful critique of legal positivism, where he einphasized the responsibility of judges to discover and make good the latent principles in a legal system-principles that are constitutive of the inoral and legal order. And the relevance of community is fully explicit in his most recent book, Law's Empire.

In "Liberal Community," Dworkin has made a case for the continuity of personal and collective identity, not only in regard to smallscale, local, or intermediate groups, but also in regard to the inore general political communities to which we belong. Dworkin inaintains that human well-being depends in part on the quality of our political comınunities. He thus disclains a disaggregative, radically pluralist pohitics, and up to a point vindicates the good sense of striving to define the public interest.

Dworkin agrees with many so-called communitarian writers that the moral environinent in which we live is a vital aspect of community and that it requires regnlation. As he rightly suggests, the moral environment must be open to influence by minorities as well as inajorities. Even so, it would seem, regulation inust establish baselines and define linits.

All this is to the good. But does Dworkin offer the best theory, or even an adequate theory, of the relation between the political cominunity and the inoral environment? Here I have iny doubts. Dworkin rehes on a favorite gambit of liberal theory-the separation of spheres. The collective life of a political comınunity, he says, "includes its official political acts: in legislation, adjudication, enforcement, and the other executive functions of government. An integrated citizen will count his cominunity's success or failure in these formal political acts as resonating in his own life, as improving or diminishing it. On the liberal view, nothing inore should be added." To be sure, each of these activities has an internal morality, itself a basis for collective integrity and its personal

$\dagger$ Professor of Law and Sociology, Emeritus, Boalt Hall School of Law, University of California, Berkeley.

1. Dworkin, Liberal Community, 77 CAlif. L. Rev. 479, 499. (1989). 
resonance. But that does not settle what should be the reach of legislation, or of executive or judicial authority.

According to Dworkin, the scope of the political community is limited to what is truly collective, that is, to activities we share as a collectivity. And, he says, there is no collective sex life, there are only the individual sex lives of individual citizens. "When we speak of a nation's sexual preferences and habits we speak statistically, not, as in the case of an orchestra's performance, of some collective achievement or disgrace."2 There are two problems here. First, although sexual preferences and behaviors are individual, and may be studied statistically, the norms that govern our sex lives are collective, as are the institutions within which regulated sex life occurs.

Second, the orchestra analogy, though effective for conveying Dworkin's concept of integration, has a grave limitation. An orchestra is a special-purpose institution. Its success may depend on concern for musicians as whole persons, for morale, for continuity, for institutional identity. But the overriding commitment is to a certain kind of performance. Everything is subordinated to musical excellence.

A political community cannot be understood in that way. The governance of a community is not a special-purpose enterprise. To govern is to accept a comprehensive responsibility for the well-being of the governed. That does not settle how the responsibility should be exercised, including how power should be distributed and limited. The well-being of the governed requires protection against arbitrary power and political overreaching. Important as that is, however, it is only part of what community needs.

There is governance, as distinct from special-purpose management, in every institution. To that extent every institution must deal with problems of community. But the political system is uniquely comprehensive. It cannot be neatly separated from the historical community or the moral community. Political institutions must make judgments affecting prosperity, education, and moral ordering. Much more than justice is at stake. Indeed, I would argue that a prime responsibility of governance is the preservation and enhancement of community. A viable community is the infra-structure of politics, and community in turn depends on political resources and political guidance.

Dworkin slips easily from "community" to "political community." Community includes politics, but much more as well, including much that is collectively experienced though not necessarily coordinated. It is the whole matrix within which people find and experience a common life. The quality of this broader communality-how people are socialized and

2. Id. at 497. 
educated; how families and other groups are constituted; how wealth and opportunity are distributed; the quality of health, work, and recreationcannot be ignored by liberal doctrine. To create a moral community, every spliere of social life must be open to scrutiny and assessment in the light of what Dworkin calls the "critical interests" of persons.

Our understanding of community as it bears on moral ordering often relies too heavily on the concept of Gemeinschaft. Although much is captured by that idea-moral unity, rootedness, intimacy, kinship-its eniphasis on unity and solidarity slights important aspects of ordinary experience. A living conununity is not likely to be completely unified or homiogeneous. As a frainework for common life it inust develop some division of labor, sonie system of authority, sonie development of roles, groups, and institutions. These structures are sustained by ongoing interdependent activities, not by symbolic experience alone; and the activities in turn require some degree of personal and group autonomy.

The basic fact is that participation in comnunities is mediated by participation in fanilies, localities, personal networks, and institutions. This "core" participation preserves the identity and rationality of the participants. Normal comnunities do not deinand irrational or self-destructive attitudes or conduct. On the contrary, without conımunity, rationality is often precarious and niay be undone. That is so nuainly because effective, mediated participation tends to restrain impulsive behavior; and because it is the nidividual's prinie resource for the development of a rational life-plan.

Even participation in "interest groups," governed by cool calculation of costs and benefits, n1ay gain in rationality if it takes place within the franiervork of conimunity. For conduct to be fully rational, the choice of ends as well as ineans must be sound. The decision to join a group or inake an investment may be unwise, not only if the project itself is dubious, but also if the initial decision to join or invest is capricious or opportunistic-not effectively governed by a defensible life-plan or by concern for broader and unintended effects. A rash investment or a highschool marriage inay turn out well, but that does not make it a sound decision. Without an informing and restraining context, reasoning about means and ends is impoverished.

Thus the deniands of community are not necessarily opposed to rational judgment and personal autonoiny. On the contrary, a radical abridgment of these values signals the distortion or destruction of counmunity. This is a major lesson of the study of "total institutions" and of totalitarian society. What we prize in community is not unity of any sort, but unity that preserves the integrity of persons, groups, and institutions. Thus understood, community is profoundly federalist in spirit and structure. It is a unity of unities. 
There is a difference, of course, between elementary autonomy and rationality-which may be compatible with very limited aspirations and considerable constraint--and a more complete realization of those values. The important point here, however, is that a normative theory of community must take them into account and not focus only on the claims of solidarity and integration. It does so in part by recognizing that community is an mherently fragile ideal precisely because it must hold in tension the often conflicting values of autonomy and integration.

It is just as wrong to make a fetish of solidarity as it is to glorify unfettered choice. Each is, in its own way, corrosive of community. The first, in reaching for total integration, turns community into a parody of itself. The second offers an ethos too thin to sustain more than a minimal moral order. A genuinely communitarian doctrine resists both extremes. It seeks theories and strategies that promise stable accommodation and conjoint fulfillment of all the values entailed by the ideal of community. These include plurality, autonony, and participation as well as historicity, mutuality, and solidarity.

This brings us to the sticking point. The source of much valid criticism of liberalism is that it lacks a robust theory of community and moral ordering. Liberalism slights values of integration and solidarity and thereby undercuts social responsibility. Dworkin has done much to enrich liberal doctrine, but he has not yet got rid of some unnecessary and burdensome baggage. He has not completed the doctrinal reconstruction needed if there is to be a inelding of liberal and communitarian principles.

Dworkin belongs to that branch of liberalism we call "contemporary" or "welfare" liberalism, to distinguish it from doctrines of laissezfaire and the minimal state. He associates liberalism with the premises of the New Deal, not with the perspectives of Ronald Reagan, Milton Friedman, or the neo-conservatives. Dworkin's liberalism is a strong and welcome voice on behalf of toleration and individual political rights. Furthermore, although he respects market mechanisms and rejects socialism, he has no difficulty justifying state intervention to achieve social justice.

The transition from laissez-faire to welfare liberalism is not new. John Stuart Mill made the passage, and his ideas prefigured a broad inovement of thought among English and American liberals in the late 19th and early 20th centuries. ${ }^{3}$ In England, influential writers like J. A. Hobson and L. T. Hobhouse insisted that liberalism (and the Liberal Party) should look to the social foundations of justice and liberty. Like

3. For England, see M. Freeden, The New Liberalism (1978); for the United States, see especially J. Dewey, Individualism, Old aNd New (1930) and Liberalism AND Social ACTION (1935). 
Mill they broadened the utilitarian perspective to include "social utility"; accepted the necessity for government intervention to enhance public welfare, especially the condition of the poor; demanded full economic opportunity and full civic participation for all sectors of society; rejected a sharp division between public and private spheres of life; developed doctrines, such as the "social property in capital," which justified regulation of private enterprise and recapture for the public of "unearned increments"; recognized that "freedom of contract" is a myth where the parties are radically unequal in social power; and emphasized the inseparability of ethics and politics, and ethics and economics. A persistent subtext was the need for a doctrine that would recognize the claims of community.

Welfare liberals do not reject the main values of their laissez-faire forebears. What they add, however, is a demand for substantive freedom, rationality, and justice. They have argued that genuine rationality cannot be realized if it is limited to individual action for individuated goals, and that justice is an illusion if it overlooks the social conditions that distort legal outcomes.

The significance of this transition has not been fully assimilated. The quest for substantive realization of key liberal values requires concern for the whole social structure as a moral environment. Furthermore, in shifting attention from individuals to commumities, welfare liberalism must deal with collective purposes. As we create and reconstruct institutions, we cannot avoid considering what ends they should serve and what duties they may prescribe. Collective action is not free of cost, and the most important cost is the energy, commitınent, discipline, and sacrifice asked of individuals in the name of community.

All this runs counter to a principle many liberals, including Dworkin, take to be a vital part of their constitutive morality. This is the idea that the pohitical community should be neutral with respect to ends. Government should not presume to say what is valuable in life, nor should it mold or constrain individual preferences. It should provide only a framework for rational discourse and peaceful competition while protecting the capacity of all individuals to seek the good in their own way. On this view, the proper locus of moral choice is the autonomous person, not collective will or judgment.

The principle of neutrality is a major obstacle to the reconciliation of liberal and communitarian perspectives. At bottom, the communitarian challenge is a demand for more extensive responsibility in every aspect of personal experience and social life. This calls for a doctrine that builds on the continuities of personal and social responsibility, personal and social integrity, individual and collective judgment. Such a 
doctrine is difficult to square with a restrictive view of what communal life entails and what judgments it may require.

It might be argued that Dworkin's paper addresses a narrow issue: the propriety of using criminal sanctions to enforce conventional morality where specific harms are not shown or are speculative. His theory, however, is not narrowly framed: more general issues of doctrine and sensibility are in play. The criminal law is a special way of exercising power, and there are very good reasons to constrain it narrowly, but what is the significance of Dworkin's theory for other forms of mandatory process? What of education, zoning, taxation, and the allocation of resources? Surely liberalism cannot be reduced to a theory of the criminal law or, more narrowly, to a rule of toleration with respect to "victimless" crimes. A general doctrine of official neutrality is too big a price to pay for policy conclusions readily reached in other ways.

Consider, for example, Dworkin's effort to defend, on liberal premises, government support for the arts. He accepts as an objective and collective judgment "that people are better off when the opportunities their culture provides are more complex and diverse, and that we should act as trustees for the future of the complexity of our own culture."4 Therefore state support is justified.

But art qualifies only on a certain premise: that state support is designed to protect structure rather than to promote any particular content for that structure at any particular time. So the ruling star of state subsidy should be this goal: it should look to the diversity and innovative quality of the culture as a whole rather than to (what public officials take to be) excellence in particular occasions of that culture. ${ }^{5}$

This argument is driven by a premise of official neutrality in aesthetic as well as moral choices. There may be standards of excellenceeven objective standards-but these are not to be defined or upheld by official authority. Diversity, innovation, and complexity are goods all may share, but no particular conception of the good should be imposed. Presumably even opportunities for criticism, debate, and reconstruction-governed by appropriate standards of representation and deliberation-are not enough to justify an authoritative collective judgment.

Is this what democracy requires? Is this any way to run a government? a university? a museum? Some liberals think so, at least some of the time, and that is an important source of communitarian unease. A policy of official neutrality seems a perverse limitation on efforts to define the public interest or the common good.

Because tyranny and oppression are ever-present threats, and for other reasons as well, we cherish democracy, plurality, and the rule of

4. R. DWorkin, A Matter of Principle 232 (1985).

5. Id. at 233 . 
law. These values, and the institutions they generate, are meant to restrain power and domesticate authority. They should not, however, be prescriptions for weak or uncommitted leadership. It is one thing to say that the state should be neutral with respect to a wide range of individual and group preferences. It is something else to turn that moral vision into an enfeebling doctrine-one that denies to the community its own funded experience, or persuasive new knowledge, regarding appropriate ends and means.

To be sure, pluralism and toleration are indispensable ingredients of the moral community. Without many different and autononious forms of expression, association, and action, oppression is virtually guaranteed and opportunities for creativity, openness, and reconstruction are closed off. But just as liberty is not license, pluralism cannot be a doctrine of anything goes. The claini to be a legitimate alternative vision of the good is not self-certifying. There should be reason to suppose that the alternatives proposed are roughly equal in moral worth or, at least, that they meet some threshold standard.

Plurality refers to an indefinite number greater than one, but it is not a synonym for boundless variety. We take for granted that there are niany worthy and even admirable ways of life-within cultures as well as among cultures. Moral, aesthetic, religious, and political pluralism must reject the idea of one right way, one right perspective, but should leave open how nrany and what kinds of choices and tradeoffs are valid or justified.

We should not confuse the fact that we sometines need to grit our teetli in the face of evil with the idea that any form of expression or action-any conception of the good, whatever its inipulse, form, or consequence-is a welcome contribution to diversity and complexity. When neo-Nazis deinonstrate in hateful ways, it is not tolerance that restrains the punitive hand of a moral community: it is a well-founded fear of slippery slopes. To protect ourselves from ourselves we need hard rules, especially rules that curb official discretion. But a claim to toleration must find its warrant in something more than self-assertion.

The Hardwick dissent is an eloquent appeal to diversity, plurality, and toleration:

The fact that individuals define themselves in a significant way through their intimate sexual relationships with others suggests, in a nation as diverse as ours, that there may be many 'right' ways of conducting those relationships, and that much of the richness of a relationship will come from the freedom an individual has to choose the form and nature of these intensely personal bonds. ${ }^{6}$

But to say that there are niany 'riglit' ways is not to say that any way is

6. Bowers v. Hardwick, 478 U.S. 186, 203 (1986). 
right, unless the use of quotation marks signals uncertainty as to the very idea of rightness.

In fact there is an underlying assumption that the alternative lifestyle-the intimate association in question-is reasonably viable, healthy, and unthreatening. The minority does not rule out prohibition of incest, adultery, prostitution, polygamy, or hoinosexual marriage. Not every intimate association is defensible, nor is every one so fundamental as to merit constitutional protection. There is no escaping the Court's specific assessment of homosexuality and its implicit conception of the good.

It is interesting that the minority opinion finds support in the Court's earlier recognition that the state's interest in public education should give way to a claim made by the Amish community in Wisconsin that extended public schooling threatened its way of life. In that case the Court said: "There can be no assumption that today's majority is 'right' and the Amish and others like them are 'wrong.' A way of life that is odd or even erratic but interferes with no rights or interests of others is not to be condemned because it is different." 7 Here too the Court assumes that the way of life in question is a morally defensible alternative to be respected and tolerated, not merely endured.

The Hardwick opinions reveal important differences in the way community and tradition are perceived. The najority is communitarian in its own way. The justices give great weight to received morality as the foundation of community and as the preserver of its identity. In the theory to which they implicitly adhere, a genuine community is a community of observance; its rules are constitutive and not inerely instrumental. A corollary is that the sense of community is best expressed in localist terms. There should be inoral autonomy at the local level, where social life is most fully experienced and appreciated. At that level, political majorities have a prima facie right to uphold conventional morality and thereby to determine the culture of the cominunity.

The dissenting justices have a quite different view. They find community and tradition in the American constitutional order. The Constitution itself is a prime source of tradition, but tradition of a special kind. It allows for change and growth, criticism and reconstruction. The tradition consists of premises and values, not particular rules and practices. To identify it we must locate implicit principles and guiding purposes. A strategy of generalization is required. In this perspective the moral order is not constituted by particularities of belief, observance, or connectedness. Rather, nore abstract ideals, such as democracy, equality, civility,

7. Wisconsin v. Yoder, 406 U.S. 205, 223-224 (1972). The Court should have said just because it is different. 
and rule of law define the conınunity. In this way, the moral conınunity is enlarged and centered on the nation as defined by the Constitution. The claims of localisin are to that extent diminished.

These conflicting perspectives point to a long-standing issue in social theory. The question is what place abstract ideas can have in the formation of community and, nideed, of personal identity and character. This is a special problem for our time because nodernty brimgs with it an attenuation of culture. It offers in exchange a universahist ethic. For the salvation of our souls we are asked to endure a thin noral order, loosely anchored in tradition, and (at least in late nodernity) a thin sense of self, one that is fluid, elusive, and vulnerable.

There is no turning back, no point in yearning for a Gemeinschaft we would not want even if it could be had. Nevertheless, as we consider the costs of nodernity we may well wish to recognize the noral worth of particularity and the limits of universalism. One way of doing so is to respect the right of a community to safeguard its inoral order, including the integrity of its institutions, and to do so without yielding principles of criticism. Defense of the noral order inakes sense sociologically as well as morally. It is difficult to raise children effectively without coinnunicating to them specific conceptions of duty and aspiration. And for inost people, identity, character, and self-regard are bound up with an historically determined sense of what is right conduct.

This presumes, however, that the conventional norality defended is an authentic part of the coninunity's history and character. We need not credit the opinions of transient inajorities; nor yield to the blandishments of "inoral entrepreneurs"; nor accept as the good coin of an ingrained sense of decency the special outlook of a moral establishinent; nor honor a "tradition" that is in fact an invention of the recent past. Above all, the clains of historicity and custom, such as they are, nuust be balanced against other elements of coininunity and noral ordering, including principles of personal autononiy, equality, and civic participation. 
. 